\title{
Coconut water uses, composition and properties: a review
}

\author{
Alexia Prades $^{1 *}$, Manuel DoRnieR ${ }^{1,2}$, Nafissatou DioP $^{3}$, Jean-Pierre PAIN ${ }^{4}$
}

${ }^{1}$ Cirad-Persyst, UMR 95 Qualisud, TA B-95 / 16,

73 rue Jean-François Breton,

F-34398 Montpellier

Cedex 5, France

alexia.prades@cirad.fr

${ }^{2}$ Montpellier SupAgro, UMR 95 Qualisud, TA B-95 / 16, 73 rue Jean-François Breton, F-34398 Montpellier Cedex 5, France

manuel.dornier@cirad.fr

3 Inst. Technol. Aliment. (ITA), route des Pères Maristes, BP 2765, Dakar, Sénégal ndiop@ita.sn

4 Univ. Montpellier II, UMR 95 Qualisud, Place Eugène Bataillon, F-34090 Montpellier, France jppain@polytech.univmontp2.fr

* Correspondence and reprints

Received 31 March 2011 Accepted 20 June 2011

Fruits, 2012, vol. 67, p. 87-107 (C) 2012 Cirad/EDP Sciences All rights reserved DOI: 10.1051/fruits/2012002 www.fruits-journal.org

RESUMEN ESPAÑOL, p. 107

\section{Coconut water uses, composition and properties: a review.}

Abstract - The product. Coconut water (Cocos nucifera L.) is an ancient tropical beverage whose popularity on the international market has been continuously increasing in recent years. Uses. Besides its various traditional uses, this refreshing liquid extracted from the coconut fruit has recently been described as a "sport beverage" and has drawn the attention of manufacturers as a natural functional drink. Composition. Coconut water has a low matter content ( $2 \%$ to $5 \%$ wet basis), mainly comprising sugars and minerals. Quality criteria, such as the water per nut ratio, Total Soluble Solids (TSS), total sugar per nut, and [reducing sugars / total sugars] ratio, are good indicators for estimating the suitability of coconut cultivars for the production of coconut water. Regarding these criteria, dwarf varieties are the most suitable cultivars to obtain a tasty product. Properties. The quality of coconut water can not only be attributed to sugars and minerals because it also has a typical flavour and some original properties. Although many authors have cited medicinal uses or growth-promoting activities, only a few publications have clearly identified the components responsible for these properties. Discussion. Results of former and recent investigations are discussed. Finally, suggestions are made for further research to increase our knowledge of this original tropical juice.

France / Cocos nucifera / coconuts / coconut water / plant developmental stages / maturation / quality / proximate composition

\section{Utilisations, composition et propriétés de l'eau de coco : une synthèse.}

Résumé - Le produit. L'eau de coco (Cocos nucifera L.) est un ancien breuvage dont la popularité est grandissante sur le marché international des boissons. Usages. Au-delà de ses usages traditionnels, ce liquide rafraîchissant extrait de la noix a été décrit comme une "boisson de réhydratation pour sportif ". Des industriels ont ainsi mis en exergue ses propriétés fonctionnelles naturelles. Composition. L'eau de coco a une faible teneur en matière sèche ( $2 \%$ à $5 \%$ en base humide), constituée de sucres et minéraux. Des critères comme le poids de l'eau par noix, les solides solubles totaux, la quantité de sucres totaux par noix, le rapport [sucres réducteurs / sucres totaux] sont de bons indicateurs pour sélectionner les cultivars adaptés à la production d'eau de coco. Au regard de ces critères, les variétés naines sont souvent les mieux adaptées à la production de cette boisson. Propriétés. La qualité de l'eau de coco est aussi liée à une flaveur typique et recherchée ainsi qu'à certaines propriétés spécifiques. Bien que plusieurs auteurs aient attribué à l'eau de coco des propriétés médicinales et aient prouvé son effet positif sur la croissance des cellules, peu de publications identifient clairement les molécules responsables de ces actions. Discussion. Pour la première fois, les recherches sur l'eau de coco, des plus anciennes au plus récentes, sont synthétisées et conduisent à proposer des pistes pour améliorer notre connaissance de ce jus de fruit tropical atypique.

France / Cocos nucifera / noix de coco / eau de coco / stade de développement végétal / maturation / qualité / composition globale 


\section{Introduction}

Coconut (Cocos nucifera L.) has been described as the most important and extensively grown palm tree worldwide. Every part of the plant is useful and, in many cases, human life would be impossible in its absence [1]. The leaf and trunk provide building material, and the root is used as medicine [2]. The fruit is the most marketable part; the envelope (mesocarp), called the husk, is processed into rope, carpets, geotextiles and growing media. The hard brown shell (endocarp) can be processed into very high-quality activated charcoal. The inner part of the nut (endosperm) is divided into two edible parts: a white kernel and a clear liquid: coconut water [3].

For more than a century, the coconut pulp or kernel has been considered as a cash crop because of its high fat content; however, nowadays, coconut is more than just an oil seed. Copra, the dried kernel, was a very important international commodity in the first part of the 20th century. Food and chemical industries processed the lauric oil extracted from copra into margarine or detergent. However, in the past 20 years, the volume of world trade in copra has decreased by $75 \%$ while the export of "fresh coconuts" has increased by $300 \%{ }^{1}$. The market for canned coconut milk, coconut cream and coconut juice/water is increasing considerably [4-6]. Coconut is no longer only an international oil commodity but is becoming a valuable fresh fruit.

Coconut water (CW) or coconut juice (not to be confused with coconut milk) is a sweet refreshing drink taken directly from the inner part of coconut fruits [7]. It differs from coconut milk, which is the oily white liquid extracted from the grated fresh kernel. In most cases, coconut water comes from small and scarce coconut tree plantations more related to "gardens". As a consequence, the coconut water remains a traditional and under-used resource which could thus be considered as an exotic beverage by most people living far from the

1 www.faostats.org (accessed 15 January, 2007). coconut production area [8]. An increasing international demand for this product could be a highly positive issue for thousands of African and Asian small farmers.

Coconut water is not only a tropical beverage but also a traditional medicine [2], a microbiological growth medium [9] and a ceremonial gift [10], and can be processed into vinegar [11] or wine [12]. These various uses are possible thanks to the original biochemical composition of the juice. The particular mineral composition and reasonable total sugar content make coconut water a natural isotonic liquid. The characteristics of coconut water make it an ideal rehydrating and refreshing drink after physical exercise [13].

Current research on coconut water is rare and mainly focuses on i) specific uses (10\%), ii) biochemical composition (50\%) and iii) preservation techniques (40\%).

This review on coconut water is the first part of a global synthesis on the topic. It presents its uses, from the traditional to the most sophisticated; details its biochemical composition, influenced by the stage of maturity and the variety; and describes its original properties. In a future Fruits issue, a second review will describe the preservation and processing of coconut water.

\section{Uses}

\subsection{As a religious symbol}

As it is a sterile and pure liquid, coconut water has been a religious symbol for a long time. In Asia, and especially in India, tender, i.e., immature, coconuts are offered as ceremonial gifts and serve as purification media at traditional events [10].

\subsection{As a natural beverage}

Centuries ago, Polynesian, Melanesian and Micronesian mariners used coconut fruits as reserves of food and drink [1]. Thanks to this "naturally canned" beverage, they survived on their journeys from one island to the next 
and colonised the entire Pacific Ocean. Nowadays, coconut water from immature nuts is still consumed as a refreshing drink by thousands of inhabitants of tropical regions. The most developed market for coconut water is Brazil, where sales of the beverage in long-life packages increased from $60 \mathrm{M}$ in 2000 to $120 \mathrm{M}$ units in $2006^{2}$ [14]. The country's top-selling brand, which was produced by Amacoco, was acquired by PepsiCo in 2009 to complement "one of the fastest growing beverage categories due to its natural bydrating qualities, great taste and nutritional benefits" according to Massimo d'Amore, chief executive officer of PepsiCo Americas Beverages ${ }^{3}$. The Coca-Cola Company has followed PepsiCo and become an investor in ZICO Beverages, a Californian company that sells coconut water ${ }^{4}$.

\subsection{As medicine}

Apart from its consumption as a natural drink, one of the most important uses of coconut water is medicinal [15]. In the Indian ayurvedic medicine, it is described as "unctuous, sweet, increasing semen, promoting digestion and clearing the urinary path" [10]. There are numerous references to medicinal uses of coconut in Sri Lanka, a country where coconut is consumed on a daily basis [2]. Out of the 40 raw or processed parts of the coconut plant cited by Ediriweera [2], five involve coconut water. Coconut water is traditionally prescribed for burning pain during urination, dysuria, gastritis, burning pain of the eyes, indigestion, hiccups or even expelling of retained placenta. In case of emergency in remote regions of the world and during World War II, coconut water was used as a short-term

2 Pagel G., Brazil's coconut water coming to a store near you, www.brazzilmag.com, article of 14/09/2004, seen on 02/03/2006.

3 Heller L., PepsiCo Brazil acquisition to make it coconut water leader, AP-Food Technology, Decision News Media, www.ap-foodtechnology.com seen on 24/ 08/2009.

${ }^{4}$ Glover K., Coke follows Pepsi into coconut water market, CBS Interact. Bus. Netw., 2009, www.BNET.com seen on 18/02/2010. intravenous hydration and resuscitation fluid $[16,17]$.

\subsection{As a growth medium for microorganisms and plants}

In the early 1960s, coconut water was already known to favour microbial growth and especially "Nata de coco" bacterium [18]. Nata de coco is bacterial cellulose naturally produced at the coconut water/air interface. Native to the Philippines, Nata de coco has become popular in many other Asian countries. The "Nata" bacterium was later identified as Acetobacter xylinum [19]. Traditionally coconut water is also processed into wine [12] or vinegar [11] due to its sugar content and ability to ferment.

Coconut water (previously called " $\mathrm{COCO}$ nut milk") has been shown to induce division of mature cells [20, 21]. For example, the growth of spinach tissue on a medium supplemented with $10 \%$ to $15 \%$ (v/v) mature coconut water increased the weight of spinach callus after 5 weeks and accelerated shoot regeneration (4-5 weeks instead of 812 weeks without) [22].

Many authors reported that coconut water contains a growth factor that stimulates different bacterial strains and in vitro culture of plants [9, 23-25]. For this purpose, coconut water from immature fruits was reported to produce better results than water from mature fruits.

\subsection{As a biocatalyst}

Coconut water appears to be able to support the synthesis of proteins from recombinant DNA vectors [26]. Filtered coconut water from young Brazilian coconuts displayed high reductase activity at ambient temperature in a series of aliphatic and aromatic aldehydes and ketones, suggesting that coconut water is probably still under-used in the organic synthesis research field [27].

\section{Biochemical composition}

The coconut fruit takes between (11 and 12) months to reach full maturity. At 


\section{A. Prades et al.}

Figure 1

Growing coconut fruit.

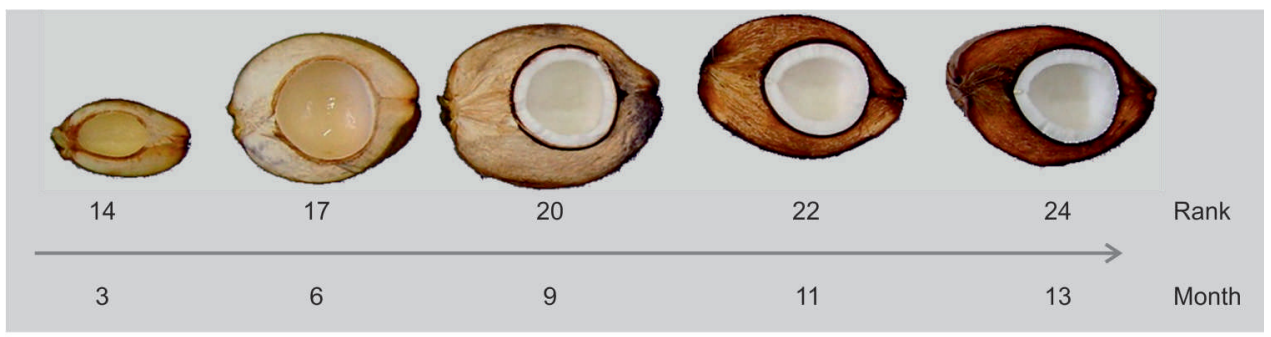

5 months, the kernel begins to form a thin layer of jelly around the inside of the endocarp or shell. The shell encloses the tender water, a clear sweet liquid. At this time the water is under pressure. During the ripening process, the pressure is released and the water is partially replaced by the kernel (figure 1). Little by little, the kernel grows and replaces the water by cells storing lipids [28]. Its composition changes as the nut grows [29]. At full maturity (12 months), coconut water represents between $15 \%$ and $30 \%$ of the weight of the nut. The amount of coconut water that can be harvested from each nut is about $300 \mathrm{~mL}$, but depends to a great extent on the stage of maturity and on the variety of coconut. There are only three types of coconut varieties: tall (allogamous), dwarf (autogamous) and hybrid; the last often being a cross between dwarf (mostly mother) and tall (father).

Coconut water in its envelope is sterile and composed of both organic and inorganic compounds (almost all minerals found in food). Compared with other fruit juices, the dry weight of mature coconut water is very low: $5 \%$ to $6 \%$ versus $12 \%$ to $15 \%$ for apple juice. The main components of coconut water are soluble sugars (table I) but it also contains proteins, salts and a very

\section{Table I.}

Composition of the mature coconut water of 13 tall, dwarf and hybrid varieties, according to different authors presented in the reference list.

\begin{tabular}{|c|c|c|c|c|c|c|c|c|c|c|c|}
\hline \multirow[t]{2}{*}{ Coconut variety } & \multirow[t]{2}{*}{$\begin{array}{l}\text { Water vol. } \\
\text { (mL per nut) }\end{array}$} & \multirow[t]{2}{*}{$\mathrm{pH}$} & $\begin{array}{l}\text { Total } \\
\text { solids }\end{array}$ & $\begin{array}{l}\text { Total } \\
\text { sugars }\end{array}$ & Sucrose & $\begin{array}{l}\text { Reducing } \\
\text { sugars }\end{array}$ & Glucose & Fructose & Proteins & Fats & Ash \\
\hline & & & \multicolumn{9}{|c|}{$\mathrm{g} \cdot 100 \mathrm{~mL}^{-1}$} \\
\hline Laguna Tall [32] & - & 5.6 & - & 3.2 & 2.4 & 0.6 & - & - & - & - & - \\
\hline Malayan Tall [40] & 385 & 5.2 & 5.6 & 4.4 & 5.1 & 2.9 & 1.5 & 1.4 & 0.51 & 0.14 & 0.46 \\
\hline West African Tall (Nigeria) [97] & 307 & 6.1 & 3.3 & - & 4.9 & - & - & - & 0.03 & - & - \\
\hline West African Tall (Côte d'Ivoire) [59] & 154 & 5.5 & 4.6 & 1.9 & - & 0.6 & - & - & - & - & - \\
\hline Golden Dwarf [32] & - & 5.5 & - & 3.2 & 2.3 & 0.8 & - & - & - & - & - \\
\hline West African Dwarf [97] & 198 & 5.2 & 5.3 & - & 5.4 & - & - & - & 0.02 & - & - \\
\hline Malayan Yellow Dwarf [59] & 229 & 5.8 & 3.9 & 2.8 & - & 0.7 & - & - & - & - & - \\
\hline Equatorial Green Dwarf [59] & 189 & 5.4 & 4.4 & 2.3 & - & 1.1 & - & - & - & - & - \\
\hline $\begin{array}{l}\text { Malayan Yellow Dwarf } \times \text { West African } \\
\text { Tall (PB121+) [59] }\end{array}$ & 238 & 5.2 & 4.9 & 2.8 & - & 1.5 & - & - & - & - & - \\
\hline Malayan Dwarf × Rennell Tall [33] & - & 5.6 & - & 2.3 & 0.1 & 2.1 & 1.7 & 0.4 & - & - & - \\
\hline Unknown variety [24] & - & - & 4.0 & 1.8 & 0.7 & 1.1 & 0.5 & 0.6 & & 0.66 & - \\
\hline Unknown variety [98] & - & 5.6 & 4.7 & 2.6 & - & - & - & - & 0.55 & 0.74 & - \\
\hline Unknown variety [31] & - & 5.1 & - & - & - & - & - & - & 0.14 & - & 0.40 \\
\hline Mean & 243 & 5.5 & 4.5 & 2.7 & 3.0 & 1.3 & 1.2 & 0.8 & 0.25 & 0.51 & 0.43 \\
\hline SD & 79 & 0.3 & 0.7 & 0.8 & 2.2 & 0.4 & 0.6 & 0.5 & 0.26 & 0.33 & 0.04 \\
\hline
\end{tabular}




\begin{tabular}{|c|c|c|c|c|c|c|c|c|c|c|c|c|}
\hline \multirow[t]{2}{*}{ K } & $\mathrm{Cl}$ & $S$ & $\mathrm{Ca}$ & $\mathrm{Na}$ & $\mathrm{Mg}$ & $P$ & $\mathrm{Mn}$ & $\mathrm{Al}$ & $\mathrm{Zn}$ & $\mathrm{Fe}$ & $\mathrm{Cu}$ & \multirow[t]{2}{*}{ References } \\
\hline & & \multicolumn{6}{|c|}{$\mathrm{mg} \cdot 100 \mathrm{~mL}^{-1}$} & \multicolumn{4}{|c|}{$\mu \mathrm{g} \cdot 100 \mathrm{~mL}^{-1}$} & \\
\hline 356 & - & - & 46.0 & 31.0 & 14.0 & - & - & - & 0.03 & - & - & [33] \\
\hline 255 & - & 4 & 31.3 & 15.9 & 9.3 & 12.6 & 0.08 & 0.06 & 0.02 & 16 & 29.3 & [40] \\
\hline 247 & 108 & 80 & 40.0 & 48.0 & 15.0 & 6.3 & - & - & - & 79 & 26.0 & [31] \\
\hline 164 & 131 & - & 18.2 & 4.1 & 7.8 & 21.0 & - & - & - & - & - & {$[38]^{\mathrm{a}}$} \\
\hline 273 & - & - & 47.7 & 45.4 & 11.7 & 9.2 & - & - & - & 112 & 28.7 & {$[39]^{a}$} \\
\hline
\end{tabular}

${ }^{a}$ For these authors, the analysed coconut water was at an unknown maturity stage.

small quantity of oil, which contributes to its very low food energy level, i.e., $44 \mathrm{cal} \cdot \mathrm{L}^{-1}$. The vitamin $\mathrm{C}$ content varies from (20 to 40) $\mathrm{mg} \cdot \mathrm{L}^{-1}$. This is not high compared with other fruits such as orange or acerola, but it is sufficient to prevent oxidation for a limited period [30]. The vitamin $B$ group is present in coconut water with $0.64 \mu \mathrm{g} \cdot \mathrm{mL}^{-1}$ of nicotinic acid and $0.52 \mu \mathrm{g} \cdot \mathrm{mL}^{-1}$ of panthotenic acid [31]

Sugars are the main fraction of soluble solids in coconut water $[32,33]$. The main sugars in mature coconut water are sucrose, sorbitol, glucose and fructose [34, 35], followed by minor sugars including galactose, xylose and mannose.

The second constituents in terms of quantity are minerals (table II). They account for only $0.4 \%$ to $1 \%$ of the liquid volume, but nevertheless contribute to its isotonic properties. The osmolarity of coconut water is about $300 \mathrm{mOsm} \cdot \mathrm{L}^{-1}$ [36-38]. Authors agreed that potassium is the main mineral element in coconut water [33, 38, 39]. According to Thampan and Rethinam, the major differences in mineral composition between immature and mature coconut water were due to potassium, chloride, iron and sulphur content [31], whereas Santoso et al. observed differences due to potassium, copper and sodium [40].

Coconut water also contains amino acids [23, 41]. Alanine, arginine, cysteine and serine contents are higher than in cow's milk [42]. One class of proteins, enzymes, has attracted the attention of several authors because they are involved in coconut water discoloration. Samples of green coconut water obtained from a Brazilian research centre and stored at $-20{ }^{\circ} \mathrm{C}$ revealed peroxydase and tyrosinase (polyphenoloxydase) activity of, respectively, (0.3 and 5.0) $\mathrm{U} \cdot \mathrm{mL}^{-1}$ [43], where $U$ is one unit of enzymatic activity defined as the amount of enzyme extract able to produce an increase in absorbance of 0.001 per minute.

Optimum activities of polyphenoloxydase (PPO) and peroxydase (POD) in green coconut water occurred at $\mathrm{pH} 6.0$ and $\mathrm{pH} 5.5$ and at temperatures of $25^{\circ} \mathrm{C}$ and $35^{\circ} \mathrm{C}$, respectively [44]. Various levels of PPO and POD activity are reported in the literature (table III). Fast Protein Liquid Chromatography (FPLC) was used to determine the retention time of the enzymes. Respective molecular weights for POD and PPO were $49.2 \mathrm{kDa}$ and $73.8 \mathrm{kDa}$ by gel filtration and $44.63 \mathrm{kDa}$ for peroxidase by electrophoresis (SDS-PAGE) [43]. These enzymes are assumed to be responsible for the discoloration (pink, yellow or brown) frequently observed in coconut water.

The [PPO / POD] ratio appears to vary considerably, ranging from 0.2 to 16.7 . Even in similar coconut varieties, it fluctuates between 0.3 and 16.7, suggesting that enzyme activity probably depends on the history of the coconut fruit: variety, cultivation conditions, stage of maturity at harvest, storage conditions of the fruit and even 
Table III.

Polyphenoloxydase (PPO) and peroxydase (POD) activities in fresh immature coconut water, according to different authors presented in the reference list.

\begin{tabular}{lcccc} 
Coconut variety, origin & PPO & POD & [PPO / POD] ratio & References \\
\cline { 2 - 3 } and maturity stage when available & \multicolumn{2}{c}{$\left(\mathrm{U} \cdot \mathrm{mL}^{-1}\right)$} & & \\
Green coconut, Brazil & 32.1 & 114.3 & 0.3 & {$[44]$} \\
Green coconut, Brazil & 16.5 & 3.6 & 4.5 & {$[102]$} \\
Green coconut, Brazil & 5.0 & 0.3 & 16.7 & {$[43]$} \\
Green Dwarf, Costa Rica, 8 months & 75.0 & 9.9 & 7.6 & {$[99]$} \\
Green Dwarf, Brazil & 2.3 & 12.2 & 0.2 & {$[100]$} \\
Green coconut, Brazil & $0.1-34.8$ & $0.1-6.2$ & $1.1-5.6$ & {$[101]$}
\end{tabular}

mode of extraction of the coconut water (involving metal tools). As for avocado fruits [45], the relative importance of the enzyme activities and their substrates, mainly phenolic compounds, probably changes at different physiological stages of the fruit.

Besides sugars, minerals and proteins, a minor fraction is composed of aromatic compounds. Coconut water has a specific taste and flavour, different from the wellknown fragrance of the coconut kernel. This beverage has a typical aroma per se which has never been fully characterised. Like organic acids composed of malic, succinic, citric, acetic and tartaric acids [24, 40], which contribute to the taste of coconut water, volatile compounds contribute to the aroma of the fresh liquid.

To our knowledge, there are only two publications describing the aromatic compounds of coconut water. The first article [46] analysed the solid phase microextraction (SPME)-headspace aroma compound of the mature water and kernel of an unknown variety of coconut from Cameroon. Aroma compounds were investigated by GC-FID (gaz chromatography flame ionisation detection) and GC/MS (gaz chromatography mass spectrum) using different achiral and chiral phase GC columns. More than 30 compounds were identified in the coconut headspace samples. The main compounds of the mature coconut water were nonanal (14.2\%), nonanol (11.2\%), heptanal $(8.2 \%)$, ethyl octanoate $(6.2 \%)$, heptanol (5.3\%) and 2-nonanol (5.1\%), while the coconut kernel was rich in delta octalactone (12.6\%), ethyl octanoate (9.6\%), nonanal (8.4\%), nonanoic acid (7.2\%), decanol (6.8\%), decanal (6.2\%) and nonanol (6.1\%). Alcohols, ketones, thiols, carboxylic acids, phenols and esters with short carbon chains were also detected in the essential oil of the coconut water, extracted by hydrodistillation and solvent extraction [47]. Among these compounds, ester n-propyl ethanoate, which was present in both extracts, is probably responsible for the flavour of coconut water (table IV). Unfortunately, the first investigation [46] was carried out using mature coconut, which is far less aromatic than immature coconut water, and the second one [47] did not mention either the exact stage of maturity, or the exact coconut varieties studied.

Even though the authors identified the same main components of coconut water, considerable variations in content were observed between investigations. These differences may be due to i) the stage of maturity of the fruits [31, 40], ii) the variety [48-50] and iii) the cultivation conditions [39, 51].

\subsection{Influence of the stage of maturity}

The most significant change during the ripening process is the volume of nut water [ 52 , 53]. As the nut matures, there is an increase in the nut water-holding capacity until the kernel begins to form a jelly inside the cavity of the fruit. Then, the water volume 
Table IV.

Aromatic compounds identified by SPME-headspace of mature coconut water from a Cameroon cultivar [46] and by hydrodistillation and solvent extraction of green and yellow coconut water (CW) from Brazil [47].

\begin{tabular}{|c|c|c|c|c|c|c|c|c|}
\hline \multicolumn{3}{|c|}{ Jirovetz et al. [46] } & \multicolumn{2}{|l|}{ Da Fonseca et al. [47] } & \multicolumn{2}{|c|}{ Hydrodistillation } & \multicolumn{2}{|c|}{ Solvent extraction } \\
\hline \multirow[t]{2}{*}{ Compounds } & \multirow{2}{*}{$\begin{array}{l}\text { Linear } \\
\text { retention } \\
\text { index }\end{array}$} & \multirow[t]{2}{*}{$\begin{array}{c}\% \text { peak } \\
\text { area }\end{array}$} & \multirow[t]{2}{*}{ Compounds } & \multirow{2}{*}{$\begin{array}{l}\text { Linear } \\
\text { retention } \\
\text { index }\end{array}$} & $\begin{array}{l}\text { Green } \\
\text { CW }\end{array}$ & $\begin{array}{l}\text { Yellow } \\
\text { CW }\end{array}$ & $\begin{array}{l}\text { Green } \\
\text { CW }\end{array}$ & $\begin{array}{l}\text { Yellow } \\
\text { CW }\end{array}$ \\
\hline & & & & & \multicolumn{2}{|c|}{$\%$ peak area } & \multicolumn{2}{|c|}{$\%$ peak area } \\
\hline 3-Methyl butanal & 654 & 1.06 & $n$-Propyl ethanoate & 750 & 15.3 & - & 53.5 & 16.7 \\
\hline Butanol & 657 & 2.17 & 1-Methylpropyl methanoate & 752 & - & - & 4.1 & - \\
\hline 2-Pentanone & 687 & 0.12 & 3-Hydroxybutan-2-one & 753 & - & - & 4.5 & 6.2 \\
\hline 2-Pentanol & 705 & 0.52 & Methyl 2-hydroxypropanoate & 754 & - & 0.9 & - & - \\
\hline 3-Methyl butanol & 737 & 0.69 & 4-Methylpentan-2-one & 759 & 12.0 & - & 29.0 & - \\
\hline Pentanol & 766 & 1.03 & Ethyl 2-hydroxypropanoate & 764 & - & - & 0.7 & - \\
\hline 2-Hexanone & 789 & traces & Butane-1,3-diol & 765 & - & - & 1.7 & 67.7 \\
\hline Hexanal & 799 & 1.27 & Butane-1,2-diol & 766 & - & - & 3.1 & 3.0 \\
\hline Hexanol & 865 & 3.02 & Butane-2,3-diol & 767 & - & - & 3.2 & 3.6 \\
\hline Heptanal & 899 & 8.16 & Ethyl carbonate & 768 & 2.1 & - & - & - \\
\hline Heptanol & 934 & 5.31 & Hexan-2-ol & 774 & - & 1.0 & - & - \\
\hline 2-Heptanol & 972 & 2.16 & $n$-Butyl ethanoate & 776 & 2.0 & & - & - \\
\hline Octanal & 1002 & 2.55 & Furfural & 781 & 14.5 & 0.8 & - & - \\
\hline Nonanal & 1005 & 14.21 & 4-Hydroxy-4-methylpentan-2-one & 784 & 30.5 & - & - & - \\
\hline Limonene & 1031 & 1.1 & 2-Hydroxy-2-methylpentane & 803 & 3.2 & - & - & - \\
\hline Octanol & 1073 & 4.31 & $p$-Menth-8-en-1-ol acetate & 873 & 1.4 & - & - & - \\
\hline 2-Nonanol & 1086 & 5.14 & Phenyl acetaldehyde & 877 & - & 0.9 & - & - \\
\hline delta-Hexalactone & 1088 & 1.48 & 4-Methoxybenzyl acetate & 1069 & - & 5.3 & - & - \\
\hline Nonanol & 1175 & 11.23 & $\begin{array}{c}\text { 7,9-Di-tert-butyl-oxaspiro[4.5]deca- } \\
\text { 6,9-diene-2,8-dione }\end{array}$ & 1235 & - & 4.5 & - & - \\
\hline Octanoic acid & 1179 & 3.53 & Methyl 6,9,12-octadecatrienoate & 1241 & - & 4.2 & - & - \\
\hline Ethyl octanoate & 1195 & 6.16 & $n$-Hexadecanoic acid (palmitic acid) & 1244 & - & 18.4 & - & - \\
\hline Decanal & 1204 & 4.17 & 3,6-Dioxane-1,8-diol & 1262 & - & 5.0 & - & - \\
\hline delta-Octalactone & 1231 & 3.17 & 3-Mercaptodecane & 1274 & - & 46.2 & - & - \\
\hline Decanol & 1267 & 3.15 & 9-Octadecenoic acid (oleic acid) & 1276 & - & 5.3 & - & - \\
\hline Nonanoic acid & 1273 & 3.13 & 9-Octadecen-1-ol & 1300 & - & 6.1 & - & - \\
\hline Undecanal & 1306 & 1.15 & Dioctyl adipate & 1304 & 11.2 & - & - & - \\
\hline Undecanol & 1365 & 3.25 & - & - & - & - & - & - \\
\hline Decanoic acid & 1371 & 1.1 & - & - & - & - & - & - \\
\hline delta-Decalactone & 1422 & 2.2 & - & - & - & - & - & - \\
\hline delta-Dodecalactone & 1530 & 1.14 & - & - & - & - & - & - \\
\hline
\end{tabular}

decreases as it is gradually used by the fruit to form the kernel.

Compared with other components of coconut water, sugars varied the most throughout the ripening process [37, 53-55]. After a period during which reports in the literature cited erroneous information orig- inating from De Kruifff [56], i.e., that "coconut water contains sucrose which becomes inverted during the maturation of the fruit", many authors including Gonzalez (1914) cited by Nathanael [57], Lahille [58] and, recently, Assa et al. [59] demonstrated that in fact the exact opposite is true. The latter 


\section{A. Prades et al.}

Figure 2

Total sugar contents of coconut water $(\% \mathrm{w} / \mathrm{v})$ of tall, dwarf, hybrid varieties and means of tall, dwarf and hybrid varieties at different stages of maturity (5-13 months) [29, 33, $37,52,53,55,57,59,96]$.

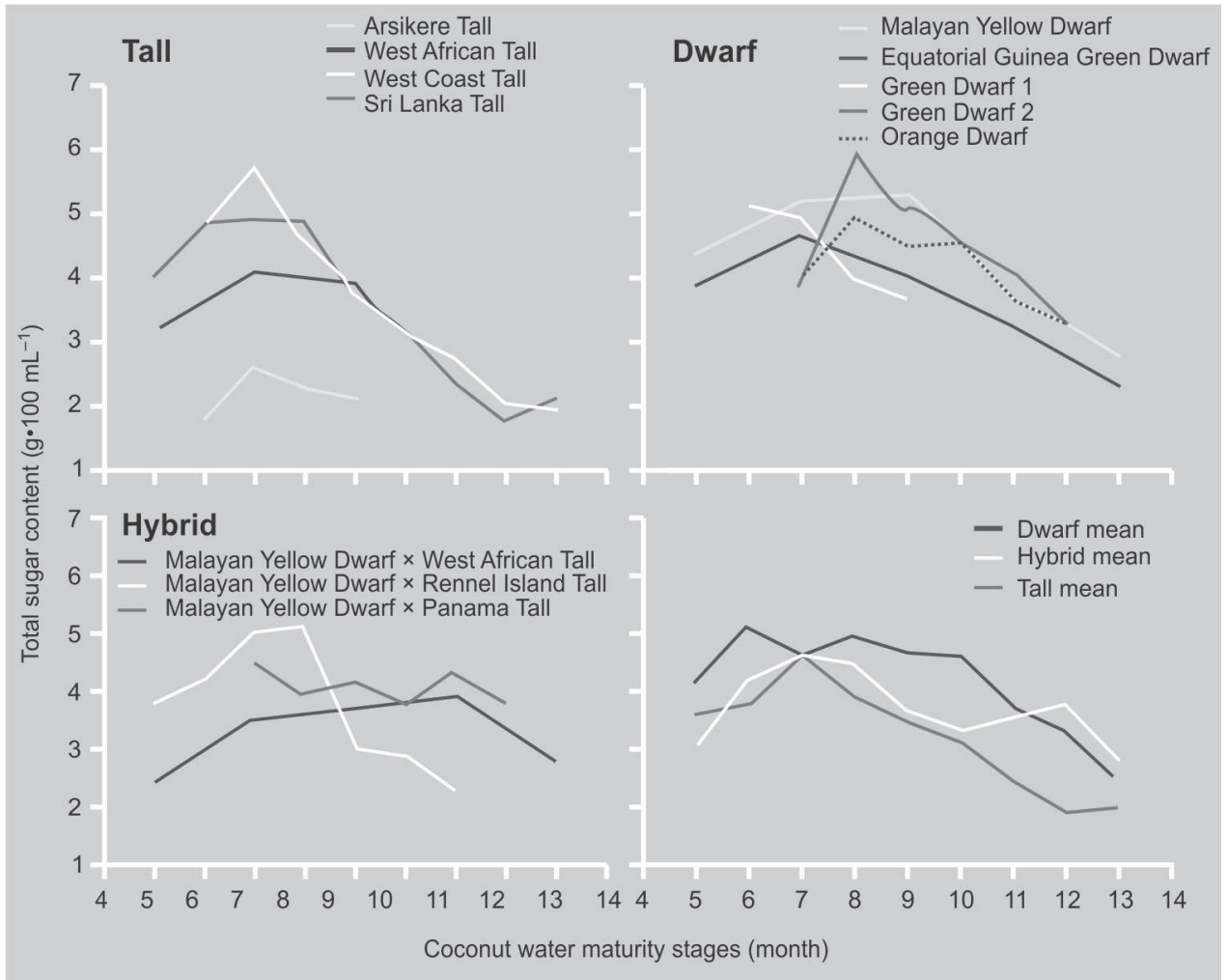

clearly showed that sucrose appeared in the coconut water aged (6 to 8 ) months. From that stage, the sucrose content increased until it comprised about $40 \%$ of total soluble sugars (TSS) at the full maturity stage, while glucose and fructose fell, respectively, from $40 \%$ to $10 \%$ of TSS and $55 \%$ to $25 \%$ of TSS during the same period.

The results of the analysis of total (TS) and reducing sugars (RS) of coconut water from 13 coconut varieties covering a maturation period of 10 months were published in ten articles between 1914 and 2008. To summarise knowledge of the ripening process, we computed and analysed these results (figures 2, 3).

In tall coconut varieties, total sugar contents (TS) of coconut water increased from 5 months to reach the maximum at 7 months (figure 2). Subsequently, total sugars rapidly decreased until full ripeness at the age of 12 months. At this stage, ripe coconut water contained around $2 \%(\mathrm{w} / \mathrm{v})$ of total sugars. In dwarf varieties, changes in total sugar content differed slightly. Like in tall varieties, changes in total sugars followed a more or less bell-shaped curve but reached the maximum at $(6,7,8$ or 9$)$ months depending on the variety and the production area. Total sugar contents of ripe coconut water of dwarf varieties were higher: between $2.5 \%$ and $3.5 \%(\mathrm{w} / \mathrm{v})$. There is a shortage of references to hybrid varieties in the literature. Only one of the studied hybrids (Malayan Yellow Dwarf $\times$ Rennel Island Tall) exhibited the same bell-curve shape. Another hybrid (Malayan Yellow Dwarf $\times$ Panama Tall, also called MAYPAN) exhibited more or less constant total sugar contents during maturation. The third hybrid (Malayan Yellow Dwarf $\times$ West African Tall, or PB121+) exhibited a slight increase in total sugars from (5 to 11) months followed by a decrease between (11 and 13) months. All coconut waters from hybrid varieties exhibited different total sugar contents and a wide range of metabolism.

Finally, the mean total sugar contents of tall, dwarf and hybrid coconut water aged from (5 to 12) months exhibited different 


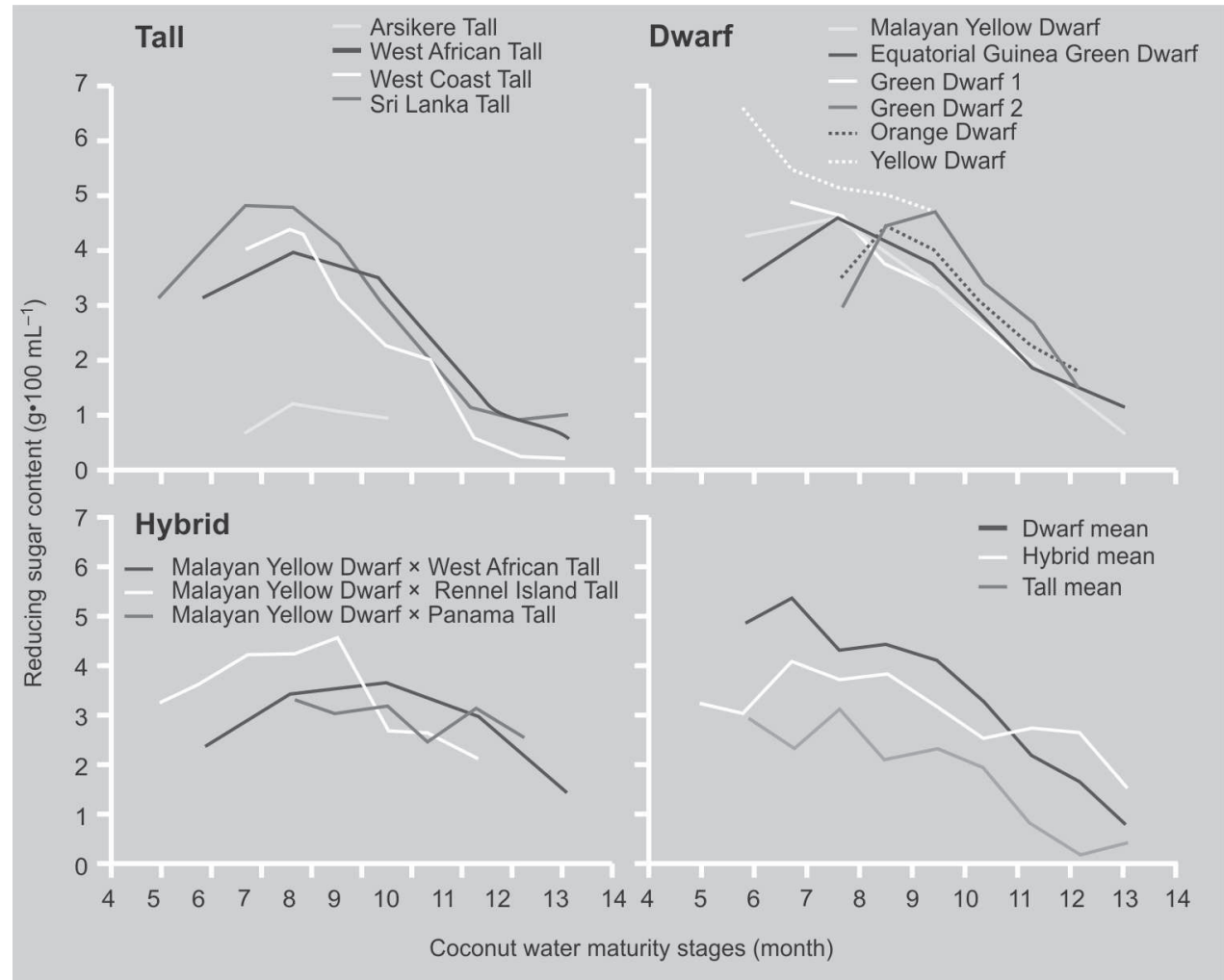

trends (figure 2). In dwarf varieties, coconut water had the highest total sugar contents and, in tall varieties, the lowest. As expected, the total sugar contents of the hybrid (dwarf $\times$ tall) coconut water were intermediate.

Changes in reducing sugar contents in the coconut water of tall, dwarf and hybrid varieties resembled those in total sugar contents (figure 3). Ripe coconut water in tall varieties had very low reducing sugar contents (nearly absent in the West Coast Tall variety). At full maturity, reducing sugars (such as glucose and fructose) were mainly replaced by sucrose. In dwarf varieties, reducing sugars remained higher than those in tall varieties, especially between ( 8 and 12) months. The particularity of the hybrids was higher reducing sugar contents at (12 and 13) months than those of tall and dwarf varieties. On average, the reducing sugar contents of coconut water in dwarf varieties was the highest throughout the ripening process, except for the last 3 months when hybrid varieties were higher. What- ever the stage of maturity, coconut water of tall varieties had the lowest reducing sugar contents.

\subsection{Influence of the variety}

At a given stage of maturity, the biochemical composition of coconut water is highly influenced by the variety. To obtain exhaustive information on the components of coconut water, data from nine articles representing 48 accessions of coconut palms and 42 different varieties were analysed (table V). The (6- to 7-) month stage was chosen because this was the stage most frequently cited in the literature. This stage of maturity is also claimed by many authors to be the most palatable for drinking coconut water. Rare data were also found on (8- or 9-) month-old fruits (not described here) $[50,59,60]$. Among the 42 varieties analysed, eighteen were tall, seventeen were dwarf and seven varieties were hybrids. Out of these, four dwarf varieties [Malayan Yellow Dwarf (MYD), Chowgat Orange Dwarf
Figure 3

Reducing sugar contents of coconut water $(\% \mathrm{w} / \mathrm{v})$ of tall, dwarf, hybrid varieties and means of tall, dwarf and hybrid varieties, at different stages of maturity (4-13 months) [29, 33, $37,52,53,55,57,59,96]$. 


\section{A. Prades et al.}

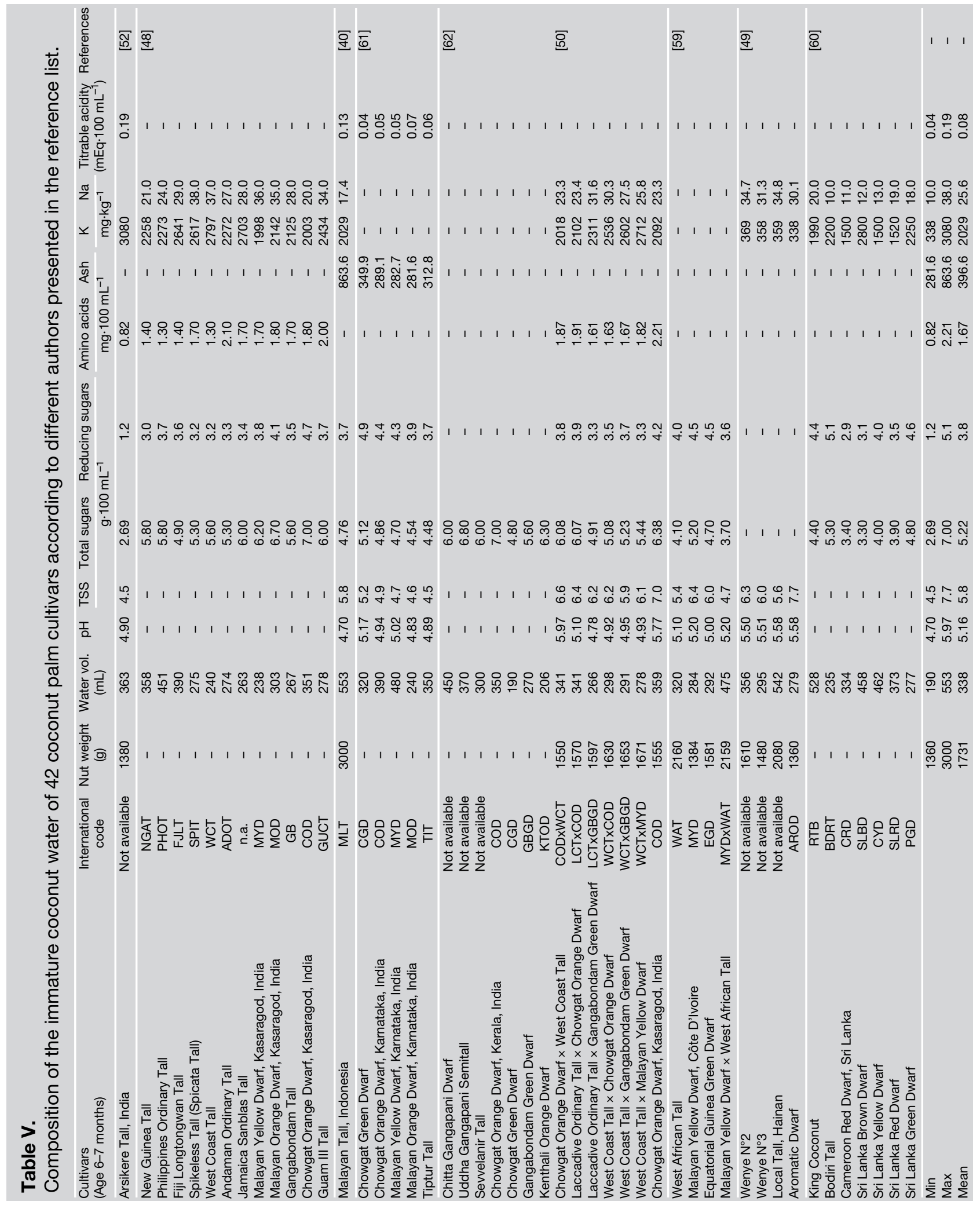




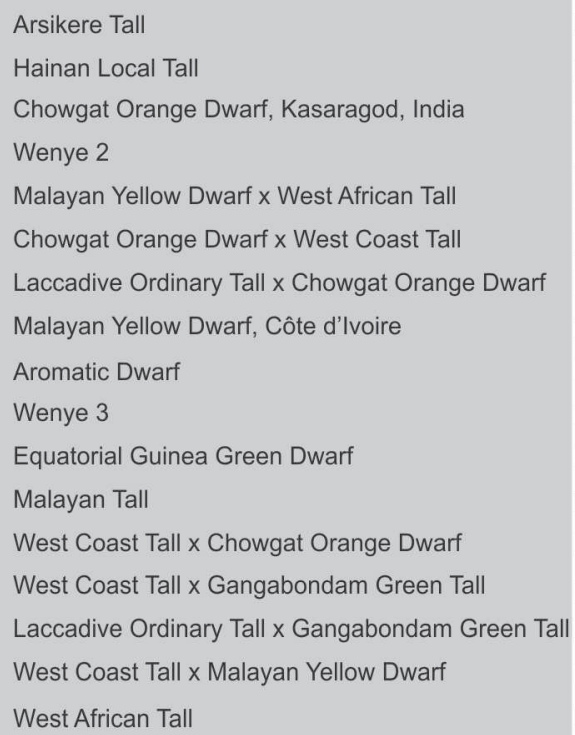

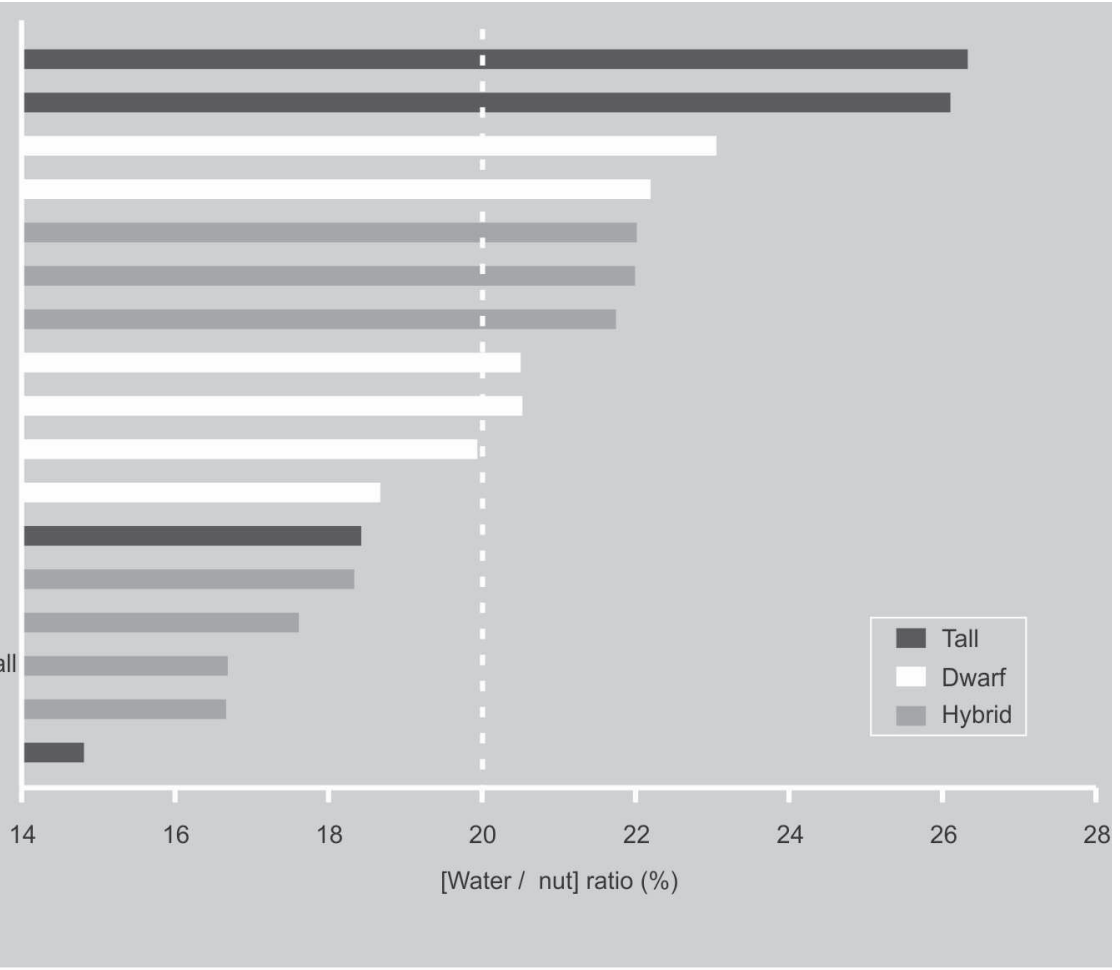

nut water production, coconut varieties with high [water / nut] ratios $(\% \mathrm{v} / \mathrm{w})$ should be selected. However, bulky biowaste can be transformed into floor and wall coverings, geotextiles, or growing media [63]. Some new uses need to be found for these byproducts and further research is required in this field.

Whatever the variety, the total sugar contents of the coconut water in 6- or 7-monthold fruits varied from one- to two-fold: in the (2.7 to 7.0 ) $\mathrm{g} \cdot 100 \mathrm{~mL}^{-1}$ range (table $\mathrm{V}$ ). The maximum amount of $7 \mathrm{~g} \cdot 100 \mathrm{~mL}^{-1}$ is close to that of orange juice $\left[(8\right.$ to 10$) \mathrm{g} \cdot 100 \mathrm{~mL}^{-1}$ ] or a soda [(from (10 to 12$) \mathrm{g} \cdot 100 \mathrm{~mL}^{-1}$ ]. At 7 months, total sugars represented more than $75 \%$ of the total soluble solids (TSS). Total sugar contents (TS) are correlated with total soluble solids $\left(R^{2}=0.622\right)$. Thus, the measurement of total soluble solids by hand refractometer might be a simple indicator for total sugar contents of 7-month-old coconuts.

By multiplying the volume of water ( $\mathrm{Vol}$ in $\mathrm{mL}$ ) by the total sugar contents (TS in $\mathrm{g} \cdot 100 \mathrm{~mL}^{-1}$ ) or by the total soluble solid contents (TSS in $\mathrm{g} \cdot 100 \mathrm{~mL}^{-1}$ ) when TS is

\section{Figure 4}

[Water / nut] ratio (\% v/w) of 17 tall (T), dwarf (D) and hybrid $(T \times D)$ coconut cultivars $[40$, $49,50,59,52]$. 


\author{
King Coconut \\ Sri Lanka Yellow Dwarf \\ West African Tall \\ Malayan Yellow Dwarf $x$ West African Tall \\ Bodiri Tall \\ Sri Lanka Green Dwarf \\ Equatorial Guinea Green Dwarf \\ Chowgat Green Dwarf \\ Sri Lanka Brown Dwarf \\ Malayan Yellow Dwarf, Karnataka, India \\ Chowgat Orange Dwarf, Karnataka, India \\ Sri Lanka Red Dwarf \\ Malayan Yellow Dwarf, Côte d'Ivoire \\ Cameroon Red Dwarf \\ Chowgat Orange Dwarf, Karnataka, India \\ Tiptur Tall \\ Fiji Lontongwan Tall \\ West Coast Tall $x$ Gangabondam Green Tall \\ West Coast Tall $x$ Chowgat Orange Dwarf \\ Laccadive Ordinary Tall $x$ Gangabondam Green Tall \\ Chowgat Orange Dwarf, Kerala, India \\ Chowgat Orange Dwarf, Kasaragod, India \\ Laccadive Ordinary Tall x Chowgat Orange Dwarf \\ Philippines Ordinary Tall \\ Chowgat Orange Dwarf $x$ West Coast Tall \\ Gangabondam Tall \\ Andaman Ordinary Tall \\ Guam III Tall \\ Malayan Yellow Dwarf, Kerala, India \\ Malayan Orange Dwarf, Kasaragod, India \\ West Coast Tall x Malayan Yellow Dwarf \\ Spikeless Tall \\ West Coast Tall \\ Jamaica Sanblas Tall \\ New Guinea Tall
}

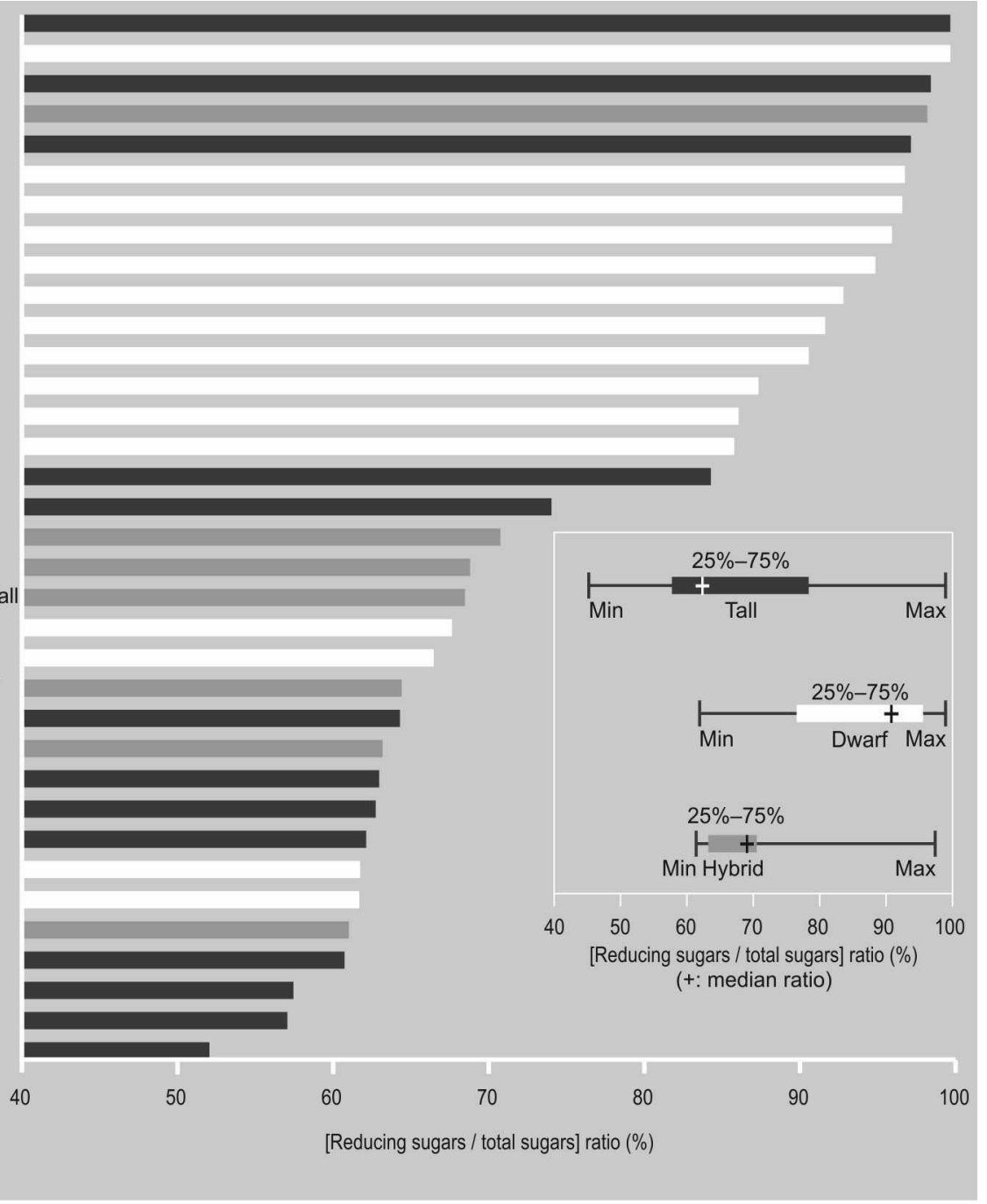

\section{Figure 5}

Ratio of reducing sugars to total sugars of the immature coconut water of 34 tall, dwarf and hybrid varieties $[40,48-50$, $52,59,61]$. correlated with TSS, [ Vol $\times$ TS (or TSS) / 100], we obtain an estimation of the total sugars per nut (g per nut). Using data from table $V$, the total quantity of sugar of one immature coconut was estimated to be in the range of $9 \mathrm{~g}$ to $27 \mathrm{~g}$ (two to six teaspoons). Depending on the desired use (drink, fermentation medium, concentrated juice, etc.), a more or less sweet variety can be selected. Using varieties with high sugar contents may help start fermentation or facilitate concentration.

Reducing sugar contents (RS) of coconut water in 7-month-old nuts ranged from (1.2 to 5.1 ) $\mathrm{g} \cdot 100 \mathrm{~mL}^{-1}$ (table V). Contrary to total sugar contents (TS), the reducing sugar contents of coconut water appeared not to be correlated with either total soluble solids or total sugar contents. The [RS / TS] ratio ranged from $52 \%$ to $99 \%$ and varied among varieties (figure 5). Most coconut water from tall varieties had [RS / TS] ratios below $75 \%$, whereas dwarf varieties generally had ratios higher than $75 \%$. Fewer data were available concerning hybrids. A classification of coconut cultivars according to the [RS / TS] ratio of their water should be possible. However, this would require further investigation in a genetic resources collection.

Concerning potassium and sodium, the coconut water of an Arsikere Tall could 
exhibit 1.5 times higher potassium contents than a Malaysian Yellow Dwarf, both cultivated in India (table $V$ ). However, mineral contents are difficult to compare among varieties, since they are strongly dependant on cultivation practices and in particular on the fertilisers or manure applied to coconut palm orchards.

\subsection{Influence of cultivation practices}

Very few publications deal with the impact of the cultivation practices on the biochemical composition of coconut water, whereas many agronomic studies deal with the impact of supplementation inputs or cultivation practices on the production of ripe nuts [64, 65]. In 1992, Jeganathan was the only investigator who used coconut water as the main ingredient for the nutritional diagnosis of the plant in comparison with the usual investigation of the leaves [66]. Coconut water was highly sensitive to fluctuations in potassium and sodium inputs and also sensitive to phosphorus, sulphur and chloride supplementation.

The effects of nitrogen-phosphoruspotassium (NPK) and nitrogen-phosphorus (NP) supplementation on coconut water quality were investigated [67, 68]. Unlike potassium, nitrogen supplementation is expected to have a negative effect on the water volume, weight and number of fruits per bunch. It appeared that potassium supplementation had an effect on the potassium content of coconut water and the amount of soluble solids in 7-month-old nuts. The effect of phosphorus supplementation appeared to be similar. Electrical conductivity was negatively correlated with $\mathrm{N}$ supplementation. The sensory analysis of coconut water in nuts from fields fertilised with NPK was normal. However, it should be noted that the investigations were only carried out on 3-year-old coconut palms [67]. Even though these were dwarf varieties, and thus premature, these coconut palms were probably not at their maximum production stage but at their growing stage. As a consequence, these results need to be confirmed in varieties after production has stabilised.

Some field irrigation trials were carried out using salty water in Brazil. Coconut palms are being planted in increasing numbers in arid and semi-arid zones of the Nordeste despite the inappropriate climate. Marinho et al. investigated field irrigation using water at different salinity rates [(0.1; $5.0 ; 10.0 ; 15.0) \mathrm{dS} \cdot \mathrm{m}^{-1}$ at $25^{\circ} \mathrm{C}$ ] [69]. These authors demonstrated that, using the green dwarf variety, nuts can be harvested at 7 months if the salinity of the irrigation water is below $10 \mathrm{dS} \cdot \mathrm{m}^{-1}$. At higher concentrations, poor yields were obtained. The salinity of the water used for irrigation led to lower fruit mean weight and lower volume of water, but increased the electrical conductivity and the amount of total soluble solids. The coconut water had higher chloride and potassium ion contents [70].

The effects of a conventional cultivation practice versus an organic cultivation system on the quality of coconut water of 7-month-old nuts were investigated [51]. Except for the fact that fruits were heavier and longer using conventional cultivation practices, no difference in the quality of the coconut water was detected between the cultivation practices. Analyses by gas chromatography with electron capture and high-performance liquid chromatography with ultra-violet detection did not detect any pesticide residues in a set of 15 coconut water samples [71]. This result emphasised the organic nature of coconut water, which is often cultivated by small-scale farmers in developing countries with no chemical inputs [72]

\section{Properties}

Most of the original properties of coconut water are due to minor components such as minerals, volatile aromatic molecules, polyols or small peptides. Only a few of the molecules responsible for medicinal or nutraceutical properties have been scientifically investigated. As a beverage, the sensorial properties of coconut water have rarely been studied, especially colour and flavour.

\subsection{Antioxidant activity}

The antioxidant ability of coconut water was recently studied by a few authors, reflecting 
the increasing interest in the nutraceutical properties of natural products. Among 27 tropical fruits purchased in supermarkets and wholesale outlets in Singapore, coconut water had the lowest AEAC (L-ascorbic acid equivalent antioxidant capacity): 11.5 AEAC $\left(\mathrm{mg} \cdot 100 \mathrm{~g}^{-1}\right)$ and an ascorbic acid (AA) content of $0.7 \mathrm{mg} \cdot 100 \mathrm{~g}^{-1}$ [73]. The coconut kernel had higher values than the coconut water. The proportion of ascorbic acid in the AEAC of fruits varied greatly among species, from $0.06 \%$ in ciku (Manilkara zapota) to $70.2 \%$ in rambutan; it was only $6.1 \%$ for coconut water.

According to Mantena et al., antioxidant activity was highest in fresh coconut water samples and decreased significantly on heating, acid or alkali treatments or dialysis [74]. The maturity of coconut drastically decreased the scavenging ability of coconut water against DPPH (1,1-diphenyl-2-picrylhydrazyl), ABTS [2,2'-azino-bis(3-ethylbenzothiazoline-6-sulphonic acid)] and superoxide radicals. Substantial antioxidant activity was also observed using the DPPH assay for extracts of two green and yellow coconut varieties obtained by hydrodistillation and petroleum ether extraction [47].

\subsection{Growth-promoting factors}

In comparison with nutrient broth, using sterilised clarified coconut water as a growth medium reduced the lag phase and enhanced the log phase of eight different microorganisms including $E$. coli and $S$. aureus [9]. Furthermore, after sterilisation and appropriate conditioning, a storage period of six months at ambient temperature did not affect the microbial growth capacity of coconut water.

Shantz and Steward first extracted some of the growth-promoting substances [75], which were later identified by Pollard et al. as sorbitol, myo-inositol and scyllo-inositol [21]. In fact, the latter (previously called cocositol) was first isolated from coconut leaves by Müller [76]. Myo-inositol was shown to play a major role in promoting cell division in carrot explants, followed by sorbitol and scyllo-inositol.
Cytokinins are a major group of phytohormones. They have different functions in plants including cell division, seed germination and tissue differentiation. Since 2004, a team of Singaporean researchers has regularly published papers on cytokinins in coconut water. In a series of seven articles Ge et al. [77-82] and Ma et al. [83] described previously uncharacterised coconut cytokinins. Nine phytohormones were detected and quantified in coconut water: zeatin-Oglucoside, dihydrozeatin-O-glucoside, kinetin (free base and riboside), which has strong anti-ageing effects on human skin [84], ZMP (trans-zeatin riboside 5'-monophosphate), gibberellins ( $\mathrm{GA}_{1}$ and $\left.\mathrm{GA}_{3}\right)$, IAA (indole-3-acetic acid) and ABA (abscisic acid). A recent review of the chemical and biological properties of coconut water detailed the biological functions of these different cytokinins in both plant and human systems [85].

The presence of both polyols and phytohormones could explain the growthpromoting action of coconut water. Despite their very interesting and important results, the authors unfortunately worked on unidentified cultivars and purchased their coconut fruits in local supermarkets. Samples were immature green coconuts from Malaysia or Thailand. Nothing was known about their growing, harvesting and storage conditions, or their stage of maturity, which could have a major influence on the quality and amount of both polyols and phytohormones.

\subsection{Medicinal and nutraceutical properties}

As coconut water is considered to be a natural medicine in different civilisations, it was screened to identify defense peptides with bactericidal properties [86]. The aim was to find novel approaches to control resistance to commercial antibiotics. Using reversedphase high-performance liquid chromatography (HPLC), three peptides $<3 \mathrm{kDa}$ were purified and identified. These small peptides, namely Cn-AMPs, had molecular masses of 858 Da, 1249 Da and $950 \mathrm{Da}$. CnAMPs showed remarkable potential for the 
development of novel antibiotics from natural sources.

The suitability of coconut water for intravenous and oral hydration has also been reported. As an intravenous fluid, Anzaldo et al. infused (500 to 700$) \mathrm{mL}$ of coconut water into nine human volunteers and did not detect any significant change either in the electrolytic composition of the blood, or in blood pressure, pulse rate or respiration [37]. But, as stated by Campbell-Falk et al., coconut water does not appear to be an ideal solution for long-term resuscitation but may serve as a temporary alternative in emergencies [16]. It should be noted that the latter result was based on mature coconut water. However, immature coconut fruits have a better mineral composition and a higher volume [87] and would be more suitable for future research on intravenous use. As an oral hydration fluid, Saat et al. compared the efficiency for rehydration after exercise of fresh young coconut water (CW), a carbohydrate-electrolyte beverage (CEB) and plain water (PW) [13]. Coconut water was significantly sweeter, caused less nausea, fullness and no stomach upset. It was also easier to drink in large quantities than the carbohydrate-electrolyte beverage and plain water.

Concerning blood pressure, a mixture of coconut water and Mauby bark syrup ( $\mathrm{Col}-$ ubrina arborescens) from Trinidad and Tobago could have a beneficial effect on human hypertension [88]. Similarly, the presence of L-arginine $\left(300 \mathrm{mg} \cdot \mathrm{L}^{-1}\right)$ in coconut water could have a cardioprotective effect through its production of nitric oxide, which favours vasorelaxation [89]. A similar hypolipidemic effect of coconut water and lovostatin (a lipid-lowering drug) was detected in rats fed a fat/cholesterol-enriched diet [90].

Concerning nutraceutical effects, coconut water reduced histopathological changes in the brain induced by hormonal imbalance in menopausal women [91]. A patented freeze-dried product, named Cococin $^{\mathrm{TM}}$, was the main component of a dietary supplement and an anti-ageing skin cream [92].

Finally, the anti-cancer properties of cytokinins previously isolated from coconut water by Ge et al. have recently been the subject of medical research [77-82]. One of these cytokinins, kinetin, shows an antithrombotic activity [93] and a real potential power to reduce certain types of mammalian tumors [94].

\subsection{Contribution to the nanoworld}

Coconut water is now entering the nanoworld. A high-quality $\mathrm{NiFe}_{2} \mathrm{O}_{4}$ nanosized powder was prepared by a new route using a natural proteic solution of coconut water and metal ions [95]. The interest in using coconut water was that it naturally contains a large protein chain which can easily bind to metal ions. The magnetic properties of the resulting nanoparticles were size-dependent. This new method of preparation was revealed to be a cheap and efficient way to obtain high-quality nickel ferrite nanosized powders.

\section{Conclusion and future prospects}

Coconut water is not a common fruit juice. Its low acidity combined with well-balanced sugar content and isotonic mineral composition makes it a potential rehydration and sport drink. Quality criteria such as the water per nut ratio, Total Soluble Solids content (TSS), total sugar per nut, [reducing sugars / total sugars] ratio, and, to a lesser extent, potassium content, are good indicators for estimating the suitability of coconut cultivars for the production of coconut water as a beverage. From the synthesis of biochemical data, it is clear that dwarf coconut varieties, with their small nuts, high volume of water, high sugar contents and good organoleptic scores, are the most suitable cultivars to obtain a sweet and tasty product.

However, the quality of coconut water can not only be attributed to sugars and minerals because it also has a typical flavour (not yet clearly characterised) and some original properties. Although many authors have cited medicinal uses or growthpromoting activities, only a few publications have clearly identified the components 
responsible for these properties and none of them studied the potential therapeutic of combined coconut water hormones and sugars (polyols). In addition, none of these studies took into account either the origin or the stage of maturity of the coconut fruits.

It is thus important to investigate the biodiversity of coconut palm. With the assistance of COGENT (International Coconut Genetic Resources Network) and Bioversity International, many collection sites around the world (Port Bouët in Côte d'Ivoire, Aracaju in Brazil, Zamboanga in the Philippines, Kasaragod in India, Santo in Vanuatu, etc.) could be screened for quality criteria and functional properties of coconut water. An international survey could improve our understanding of the effects of climate and cultural conditions on the quality of coconut water. Such an investigation could lead to the discovery of the most suitable varieties for coconut water beverages or the emergence of some lead compounds for future medicine.

\section{Acknowledgements}

The authors wish to acknowledge Dr. Olivier Gibert and Mrs Daphne Goodfellow for the English revision of the manuscript.

\section{References}

[1] Bourdeix R., Konan J.L., N'Cho Y.P., Coconut: a guide to traditional and improved varieties, Ed. Diversiflora, Montpellier, France, 2005.

[2] Ediriweera E.R.H.S.S., Medicinal uses of coconut (Cocos nucifera L.), Cocoinfo Int. 10 (2003) 11-21.

[3] Pieris W.V.D., L'eau de coco, constituant liquide de l'endosperme de la noix de coco, Note sur la terminologie, Oléagineux 26 (1971) 383-390.

[4] Batugal P.A., Ramanatha Rao V., Bong C., Promoting multi-purpose uses and competitiveness of the coconut, in: Batugal P.A., Ramanatha Rao V., Bong C.E. (Eds.), IPGRI, Chumphon, Thailand, 1996.
[5] Chandrasekharan V.G., Remany G., Mathew T.M., Exploring trade opportunities for coconut products - An experience from New Delhi, Indian Coconut J. 35 (2004) 22-24.

[6] De Leon S.Y., Delores M.I., Coconut, in: Barrett D.M., Somogyi L.P., Ramaswamy H.S. (Eds.), Processing fruits: science and technology, Boca Raton, Fla., U.S.A., 2005.

[7] Steiner I., Desser A., Coconut water - composition, properties and processing, Ernähr. 32 (2008) 513-516.

[8] Jordana J., Traditional foods: challenges facing the European food industry, Food Res. Int. 33 (2000) 147-152.

[9] Osazuwa O.E., Ahonkhai I., Coconut water as growth medium for micro-organisms, Niger. J. Palms Oil Seeds 10-11 (1989) 9195.

[10] Rethinam P., Kumar T.B.N., Tender coconutan overview, Indian Coconut J. 32 (2001) 222.

[11] Sanchez P.C., Collado L.S., Gerpacio C.L., Lapitan H., Village level technology of processing coconut water vinegar, Philipp. Agric. (1985) 439-448.

[12] Augustine S.P., Wine produced using tender coconut and product, Patent US2007/ 017897 A1, Inde, 2007.

[13] Saat M., Singh R., Gamini Sirisinghe R., Nawawi M., Rehydration after exercise with fresh young coconut water, carbohydrateelectrolyte beverage and plain water, J. Physiol. Anthropol. Appl. Hum. Sci. 21 (2002) 93-104.

[14] De Carvalho J.M., Maia G.A., de Sousa P.H.M., Maia Jr. G.A., Água-de-coco: propriedades nutricionais, funcionais e processamento, Semin.: Ciênc. Agrar. 27 (2006) 437-452.

[15] Nanda Kumar T.B., Tender coconut water: nature's finest drink, Indian Coconut J. 21 (1990) 14-18.

[16] Campbell-Falck D., Thomas T., Falck T.M., Tutuo N., Clem K., The intravenous use of coconut water, Am. J. Emerg. Med. 18 (2000) 108-111.

[17] Pummer S., Heil P., Maleck W., Petroianu G., Influence of coconut water on hemostasis, Am. J. Emerg. Med. 19 (2001) 287-289.

[18] Alaban C.A., Studies on the optimum conditions for "nata de coco" bacterium or "nata" formation in coconut water, Philipp. Agric. 45 (1962) 490-516. 
[19] De Gallardo J.E., Andres R.M., Magno E.T., A study on the isolation and screening of microorganisms for production of diversetextured nata, Philipp. J. Sci. 100 (1971) 4151.

[20] Van Overbeek J., Conklin M.E., Blakeslee A.F., Factors in coconut milk essential for growth and development of very young Datura embryos, Science 94 (1941) 350351.

[21] Pollard J.K., Shantz E.M., Steward F.C., Hexitols in coconut milk: their role in nurture of dividing cells, Plant Physiol. (1961) 492501.

[22] Al-Khayri J., Huang F., Morelock T., Busharar T., Spinach tissue culture improved with coconut water, HortScience 27 (1992) 357358.

[23] Sierra Z.N., Velasco J.R., Studies on the growth factor of coconut water - Isolation of the growth promoting activity, Philipp. J. Coconut Stud. 1 (1976) 11-18.

[24] Unagul P., Assantachai C., Phadungruengluij S., Suphantharika M., Tanticharoen M., Verduyn C., Coconut water as a medium additive for the production of docosahexaenoic acid (C22:6 n3) by Schizochytrium mangrovei Sk-02, Bioresour. Technol. 98 (2007) 281-287.

[25] Anith K.N., Mature coconut as a bio-fermentor for multiplication of plant growth promoting rhizobacteria, Current Sci. 97 (2009) 1647-1653.

[26] Bustamante J.O., New biotechnological applications of coconuts, Electron. J. Biotechnol. 7 (2004) 5.

[27] Da Fonseca A.M., Monte F.J.Q., de Oliveira M. da C.F., de Mattos M.C., Cordell R., Braz-Fliho G.A., Lemos T.L.G., Coconut water (Cocos nucifera L.) - A new biocatalyst system for organic synthesi,. J. Mol. Catal. B: Enzym. 57 (2009) 78-82.

[28] Henry P., Recherches sur la croissance et le développement chez Elaeis guineensis Jacq. et chez Cocos nucifera L., Comparaisons avec quelques autres palmiers, Univ. Paris, Fac. Sci., Thèse, Orsay, France, 1957, 154 p.

[29] Jayalekshmy A., Arumughan C., Narayanan C.S., Mathew A.G., Changes in the chemical composition of coconut water during maturation, J. Food Sci. Technol. 23 (1986) 203207.

[30] Dupaigne P., Un jus de fruit peu ordinaire : l'eau de coco, Fruits 26 (1971) 625-627.
[31] Thampan P.K., Rethinam P., Coconut products for health and medicine, Indian Coconut J. 35 (2004) 6-15.

[32] Lapitan O.B., Mabesa R.C., Chemical and sensory characteristics of Laguna and Golden coconuts (Cocos nucifera L.), Philipp. Agric. 66 (1983) 144-150.

[33] Pue A.G., Rivu W., Sundarrao C., Singh K., Preliminary studies on changes in coconut water during maturation of the fruit, Sci. New Guin. 18 (1992) 81-84.

[34] Del Rosario J.E., Bergonia H.A., Flavier M.E., Samonte J.L., Mendoza E.M.T., Chromatographic analysis of carbohydrates in coconut water, Trans. the Natl. Acad. Sci. Technol. 6 (1984) 127-151.

[35] Ogundiya M.O., Glucose content of nut water in four varieties of coconut palm (Cocos nucifera), J. Sci. Food Agric. 56 (1991) 399-402.

[36] Chavalittamrong B., Pidatcha P., Thavisri U., Electrolytes, sugar, calories, osmolarity and $\mathrm{pH}$ of beverages and coconut water, Southeast Asian J. Trop. Med. Public Health 13 (1982) 427-431.

[37] Anzaldo F.E., Kintinar Q.L., Recto P.M., Velasco R.U., De La Cruz F., Jacalne A., Coconut water as intravenous fluid, Philipp. J. Coconut Stud. 10 (1985) 31-43.

[38] Richter E.M., Jesus D.P. de, Muñoz R.A.A., Lago C.L.d., Angnes L., Determination of anions, cations, and sugars in coconut water by capillary electrophoresis, J. Braz. Chem. Soc. 16 (2005) 1134-1139.

[39] Uphade B.K., Shelke S.S., Thorat D.G., Studies on some physico-chemical characteristics of coconut water near sugar and chemical factory, Kopergaon (M.S.), Int. J. Chem. Sci. 6 (2008) 2052-2054.

[40] Santoso U., Kubo K., Ota T., Tadokoro T., Maekawa A., Nutrient composition of kopyor coconuts (Cocos nucifera L.), Food Chem. 57 (1996) 299-304.

[41] Shivashankar S., Biochemical changes during fruit maturation in coconut, J. Plant. Crops. 19 (1991) 102-119.

[42] Woodroof J.G., Coconut storage and processing, and minor uses of products of the coconut tree, in: Coconuts: production, processing, products, Ed. AVI Publ. Co., Westport, Conn., U.S.A., 1970.

[43] Duarte A.C.P., Coelho M.A.Z., Leite S.G.F., Identification of peroxidase and tyrosinase in 
green coconut water, Cienc. Tecnol. Aliment. 3 (2002) 266-270.

[44] Campos C.F., Souza P.E.A., Coelho J.V., Gloria M.B.A., Chemical composition, enzyme activity and effect of enzyme inactivation on flavor quality of green coconut water, Philipp. J. Coconut Stud. 20 (1996) 487-500.

[45] Golan A., Kahn V., Sadovski A.Y., Relationship between polyphenols and browning in avocado mesocarp. Comparison between the Fuerte and Lerman cultivars, J. Agric. Food Chem. 25 (1977) 1253-1260.

[46] Jirovetz L., Buchbauer G., Ngassoum M.B., Solid-phase-microextraction-headspace aroma compounds of coconut (Cocos nucifera L.) milk and meat from Cameroon, Ernähr. 27 (2003) 300-303.

[47] da Fonseca A.M., Bizerra A.M.C., da Souza J.S.N., Monte F.J.Q., de Oliveira M. de C.F., de Mattos M.C., Cordell G.A., Braz-Filho R., Lemos T.L.G., Constituents and antioxidant activity of two varieties of coconut water (Cocos nucifera L.), Rev. Bras. Farmacogn. 19 (2009b) 193-198.

[48] Dhamodaran S., Ratnambal M.J., Chempakam B., Pillai R.V., Viraktamath B.C., Evaluation of tendernut water in coconut cultivars, in: Nair M.K., Khan H.H., Gopalasundaram P., Bhaskana Rao E.N.V. (Eds.), Advances in Coconut Research and Development, ISOCRAD II Oxford \& IBH Publ. Co. PVT Ltd., New Delhi, India, 1993.

[49] Wang P., Liu L., Dong Z., Feng M., Li Y., Tang L., Characteristics and mineral elements of tender coconut water in different coconut (Cocos nucifera L.) cultivars, J. Fruit Sci. 25 (2008) 601-603.

[50] Apshara S.E., Kumaran P.M., Arunachalam V., Jayabose C., Evaluation of coconut hybrids for suitability as tender nut, Indian Coconut J. 38 (2007) 20-23.

[51] Da Silva D.L.V., Alves R.E., de Figueiredo R.W., Maciel V.T., de Farias J.M., de Aquino A.R.L., Características físicas, físico-químicas e sensoriais da água de frutos de coqueiro anão verde oriundo de produção convencional e orgânica, Ciênc. Agrotecnol. 33 (2009) 1079-1084.

[52] Chikkasubbanna V., Jayaprasad K.V., Subbaiah T., Poonacha N.M., Effect of maturity on the chemical composition of tender coconut (Cocos nucifera L. var. Arsikere Tall) water, Indian Coconut J. 20 (1990) p.10-13.
[53] Jackson J.C., Gordon A., Wizzard G., McCook K., Rolle R., Changes in the chemical composition of coconut (Cocos nucifera) water during maturation of the fruit, J. Sci. Food Agric. 84 (2004) 1049-1052.

[54] Child R., Nathanael W.R.N., Changes in the sugar composition of coconut water during maturation and germination, J. Sci. Food Agric. 1 (1950) 326-329.

[55] Kwiatkowski A., Clemente E., Scarcelli A., Batista V., Quality of coconut water 'in natura' belonging to Green Dwarf fruit variety in different stages of development, in plantation on the northwest area of Parana, Brazil, Int. J. Food Agric. Environ. 6 (2008) 102-105.

[56] De Kruijff E., Composition of coconut water and presence of diastase in coconuts, Bull. Dép. Agric. Indes Néerl. 4 (1906) 1-8.

[57] Nathanael W.R.N., The sugars of coconut water, Ceylon Coconut Q. 3 (1952) 193-199.

[58] Lahille A., L'eau de coco - ses caractères sa composition - ses divers emplois, Bull. Écon . Indoch. 140 (1920), 1-25.

[59] Assa R.R., Konan J.L., Agbo N., Prades A., Nemlin J., Caractéristiques physicochimiques de l'eau des fruits de quatre cultivars de cocotier (Cocos nucifera L.) en Côte d'Ivoire, Agron. Afr. 19 (2007) 41-51.

[60] Ranasinghe C.S., Madurapperuma W.S., Nainanayake N.P.A.D., Mendis H.C., Fernando W.P.K.K., Tender coconuts for export market: evaluation of cultivars and improved protocol for extended shelf-life, Indian Coconut J. 51 (2009) 18-25.

[61] Nadanasabapathy S., Kumar R., Physicochemical constituents of tender coconut (Cocos nucifera) water, Indian J. Agric. Sci. 69 (1999) 750-751.

[62] Samsudeen K., Niral V., Jerard B.A., Kumaran P.M., Native tendernut cultivars of coconut (Cocos nucifera L.) from India, Indian Coconut J. 36 (2006) 10-13.

[63] Wazir S.K.S., Technologies on environmentfriendly young tender coconuts, in: Proc. Cocotech Meeting, APCC, Manila, Philipp., 1997.

[64] Magat S.S., Coconut productivity factors: environment, nutrition and crop variety, Coconuts Today (1988) 45-53.

[65] Ouvrier M., Exportation par la récolte du cocotier PB-121 en fonction de la fumure potassique et magnésienne, Oléagineux 39 (1984) 263-268. 
[66] Jeganathan M., Nut water analysis as a diagnostic tool in coconut nutrition studies, Commun. Soil Sci. Plant Anal. 23 (1992) 2667-2686.

[67] Da Silva R.A., Cavalcante L.F., de Holanda J.S., Pereira W.E., de Moura M.F., Ferreira Neto M., Fruits quality of green dwarf coconut fertirrigation with nitrogen and potassium, Rev. Bras. Frutic. 28 (2006) 310-313.

[68] Teixeira L.A.J., Bataglia O.C., Buzetti S., Furlani Jr. E., Dos Santos Isepon J., NPK fertilization on Dwarf Green coconut (Cocos nucifera L.) - Yield and fruit quality, Rev. Bras. Frutic. 27 (2005) 120-123.

[69] Marinho F.J.L., Gheyi H.R., Fernandes P.D., de Holanda J.S., Ferreira Neto M., Cultivo de coco 'Anao Verde' irrigado com aguas salinas, Pesqui. Agropecu. Bras. 41 (2006) 1277-1284.

[70] Ferreira Neto M., Gheyi H.R., de Holanda J.S., de Medeiros J.F., Fernandes P.D., Qualidade do fruto verde de coqueiro em função da irrigação com água salina, Rev. Bras. Eng. Agríc. Ambient. 6 (2002) 69-75.

[71] Brito N.M., Navickiene S., Polese L., Jardim E.F.G., Abakerli R.B., Ribeiro M.L., Determination of pesticide residues in coconut water by liquid-liquid extraction and gas chromatography with electron-capture plus thermionic specific detection and solid-phase extraction and high-performance liquid chromatography with ultraviolet detection, J. Chromatogr. A. 957 (2002) 201-209.

[72] Assa R.R., Konan J.L., Nemlin J., Prades A., Agbo N.z., Sie R.S., Diagnostic de la cocoteraie paysanne du littoral ivoirien, Sci. Nat. 3 (2006) 113-120.

[73] Leong L.P., Shui G., An investigation of antioxidant capacity of fruits in Singapore markets, Food Chem. 76 (2002) 69-75.

[74] Mantena S.K., Jagadish, Badduri S.R., Siripurapu K.B., Unnikrishnan M.K., In vitro evaluation of antioxidant properties of Cocos nucifera Linn. Water, Nahrung 47 (2003) 126-131.

[75] Shantz E.M., Steward F.C., Coconut milk factor: the growth promoting substances in coconut milk, J. Am. Chem. Soc. 74 (1952) 6133-6135.

[76] Müller H., CLXVI. - Cocositol (cocosite), a constituent of the leaves of Cocos nucifera and Cocos plumosa, J. Chem. Soc. Trans. 91 (1907) 1767-1780.
[77] Ge L., Peh C.Y.C., Yong J.W.H., Tan S.N., Hua L., Ong E.S., Analyses of gibberellins by capillary electrophoresis-mass spectrometry combined with solid-phase extraction, J. Chromatogr. A. 1159 (2007) 242-249.

[78] Ge L., Yong W.H., Tan S.N., Yang X.H., Ong E.S., Analysis of some cytokinins in coconut (Cocos nucifera L.) water by micellar electrokinetic capillary chromatography after solidphase extraction, J. Chromatogr. A. 1048 (2004) 119-126.

[79] Ge L., Yong J.W.H., Goh N.K., Chia L.S., Tan S.N., Ong E.S., Identification of kinetin and kinetin riboside in coconut (Cocos nucifera L.) water using a combined approach of liquid chromatography-tandem mass spectrometry, high performance liquid chromatography and capillary electrophoresis, J. Chromatogr. B. 829 (2005) 26-34.

[80] Ge L., Yong J.W.H., Tan S.N., Hua L., Ong E.S., Analyses of gibberellins in coconut (Cocos nucifera L.) water by partial fillingmicellar electrokinetic chromatographymass spectrometry with reversal of electroosmotic flow, Electrophoresis 29 (2008) 2126-2134.

[81] Ge L., Yong J.W.H., Tan S.N., Ong E.S., Determination of cytokinins in coconut (Cocos nucifera L.) water using capillary zone electrophoresis-tandem mass spectrometry, Electrophoresis 27 (2006) 2171-2181.

[82] Ge L., Yong J.W.H., Tan S.N., Yang X.H., Ong E.S., Analysis of cytokinin nucleotides in coconut (Cocos nucifera L.) water using capillary zone electrophoresis-tandem mass spectrometry after solid-phase extraction, J. Chromatogr. A. 1133 (2006) 322-331.

[83] Ma Z., Ge L., Lee A.S.Y., Yong J.W.H., Tan S.N., Ong E.S., Simultaneous analysis of different classes of phytohormones in coconut (Cocos nucifera L.) water using high-performance liquid chromatography and liquid chromatography-tandem mass spectrometry after solid-phase extraction, Anal. Chim. Acta 610 (2008) 274-281.

[84] Rattan S.I.S., Clark B.F.C., Kinetin delays the onset of aging charactistics in human fibroblasts, Biochem. Biophys. Res. Commun. 201 (1994) 665-672.

[85] Yong J.W.H., Liya G., Fei N.Y., Ngin T.S., The chemical composition and biological properties of coconut (Cocos nucifera L.) water, Molecules 14 (2009) 5144-5164.

[86] Mandal S., Dey S., Mandal M., Sarkar S., Maria-Neto S., Franco O., Identification and 
structural insights of three novel antimicrobial peptides isolated from green coconut water, Peptides 30 (2009) 633-637.

[87] Goldsmith H.S., Coco-nut water for intravenous therapy, Br. J. Surg. 49 (1961) 421-422.

[88] Alleyne T., Roache S., Thomas C., Shirley A., The control of hypertension by use of coconut water and mauby: two tropical food drinks, West Indian Med. J. 54 (2005) 3-8.

[89] Anurag P., Sandhya V., G, Rajamohan T., Cardioprotective effect of tender coconut water, Indian Coconut J. 37 (2007) 22-25.

[90] Sandhya V.G., Rajamohan T., Comparative evaluation of the hypolipidemic effects of coconut water and lovastatin in rats fed fatcholesterol enriched diet, Food Chem. Toxicol. 46 (2008) 3586-3592.

[91] Radenahmad N., Saleh F., Sawangjaroen K., Rundorn W., Withyachumnarnkul B., Connor J.R., Young coconut juice significantly reduces histopathological changes in the brain that is induced by hormonal imbalance: a possible implication to postmenopausal women, Histol. Histopathol. 24 (2009) 667-674.

[92] Prakash L., Natural ingredients nurture skin health from the inside and out, NutraCos 7 (2008) 6-9.

[93] Hsiao G., Shen M.-Y., Lin K.-H., Chou C.-Y., Tzu N.-H., Lin C.-H., Chou D.-S., Chen T.-F., Sheu J.-R., Inhibitory activity of kinetin on free radical formation of activated platelets in vitro and on thrombus formation in vivo, Eur. J. Pharmacol. 465 (2003) 281-287.

[94] Vermeulen K., Strnad M., Krytof V., Havlíck L., Van $\operatorname{der}$ Aa A., Lenjou M., Nijs G., Rodrigus I., Stockman B., van Onckelen H., Van Bockstaele D.R., Berneman Z.N., Antiproliferative effect of plant cytokinin analogues with an inhibitory activity on cyclindependent kinases, Leukemia 16 (2002) 299-305.
[95] De Paiva J.A.C., Graca M.P.F., Monteiro J., Macedo M.A., Valente M.A., Spectroscopy studies of $\mathrm{NiFe}_{2} \mathrm{O}_{4}$ nanosized powders obtained using coconut water, J. Alloys Compd. 485 (2009) 637-641.

[96] Costa L.M.C., Maia G.A., de Costa J.M.C., de Figueiredo R.W., Rodrigues M. de C.P., de Sousa P.H.M., Pinheiro A.M., Qualidade e vida de prateleira da agua de coco obtida pelo processo de enchimento a quente, Rev. Bras. Armaz. 31 (2006) 95-102.

[97] Enonuya O.M.D., High performance liquid chromatographic analysis of nutwater syrup fractions from two varieties of Nigerian coconuts (Cocos nucifera L.), Niger. J. Palms Oil Seeds 9 (1988) 48-58.

[98] Sison B.C.J., Disposal of coconut processing waste, Philipp. J. Coconut Stud. 11 (1977) 39-41.

[99] Diop N., Caractérisation physico-chimique de l'eau de la noix de coco verte (Cocos nucifera L.) et essais de stabilisation par techniques membranaires, ENSIA-SIARC, Master thesis, Montpellier, France, 2005, $132 \mathrm{p}$.

[100]Abreu L.F., Faria J. de A.F., Influencia da temperatura e do acido ascorbico sobre a estabilidade fisico-quimica e atividade enzimatica da agua de coco (Cocos nucifera L.) acondicionada assepticamente, Cienc. Tecnol. Aliment. 27 (2007) 226-232.

[101]Murasaki-Aliberti N.D., da Silva R.M.S., Gut J.A.W., Tadini C.C., Thermal inactivation of polyphenoloxidase and peroxidase in green coconut (Cocos nucifera) water, Int. J. Food Sci. Technol. 44 (2009) 2662-2668.

[102] Kikuda A.T., Tadini C.C., Fernandes R., Modelo de primeira ordem multicomponente para inativação térmica em processo descontínuo da peroxidase e polifenoloxidase presentes na água de coco verde (Cocos nucifera L.), in: CBCTA A.d.X. (Ed.), XVIII Cong. Bras. Ciênc. Tecnol. Alim., Porto Alegre, Brazil, 2002. 


\section{Usos, composición y propiedades del agua de coco: una síntesis.}

Resumen - El producto. El agua de coco (Cocos nucifera L.) es una antigua bebida, cuya popularidad es cada vez mayor en el mercado multinacional de los refrescos. Usos. Más allá de su uso tradicional, este jugo refrescante extraído del coco se describió como una " bebida rehidratante para los deportistas ". De ahí que la industria resaltara las propiedades funcionales naturales de este fruto. Composición. El agua de coco posee un bajo contenido de materia seca ( $2 \%$ a $5 \%$ en base húmeda), compuesta, a su vez, por azúcares y minerales. Para seleccionar los cultivares adaptados a la producción de agua de coco, algunos de los siguientes criterios son muy buenos: el peso del agua por fruto, los sólidos totales solubles, la cantidad de azúcares totales por fruto, la relación [azúcares reductores / azúcares totales]. Habida cuenta de dichos criterios, con frecuencia, las variedades enanas son las que mejor se adaptan a la producción de este refresco. Propiedades. Asimismo, la calidad del agua de coco está relacionada a un sabor típico e intenso y a ciertas propiedades específicas. A pesar de que numerosos autores hayan atribuido al agua de coco unas propiedades medicinales y hayan demostrado su efecto positivo en el crecimiento de las células, aún existen pocas publicaciones que identifiquen claramente las moléculas responsables de dichas acciones. Discusión. Por primera vez, están recopiladas todas las investigaciones sobre el agua de coco, desde las más antiguas hasta las más recientes, y proponen nuevas pistas para mejorar nuestro conocimiento sobre este original zumo de fruta tropical.

Francia / Cocos nucifera / coco / agua de coco / etapas de desarrollo de la planta / maduración / calidad / composición aproximada 